\title{
A Case for Teaching Pronunciation to Adult EFL Learners, Using Metrical Versification
}

\author{
Mahboobeh Khaleghi \\ University of Mysore, India \\ Manal Batobara \\ Department of European Languages and Literature, \\ University of Jeddah, KSA \\ Mohammad Saleem \\ Department of English, King Abdulaziz University - Rabigh branch \\ Rabigh, KSA
}

\begin{abstract}
Accent, rhythm, and intonation are significant features of the English language. The Intelligibility of EFL learners' speech is largely affected for lack of knowledge of correct use (or no use) of these suprasegmental features in the oral production of English. The preuniversity EFL curriculum in Saudi Arabia ignores the teaching of suprasegmental features, whereas training in suprasegmental features should be an essential aspect of EFL teaching. Metrical poetry can be used as a practical medium to teach accent, rhythm, and intonation in speech. The two-fold objectives of the present research were (i) to test the efficacy of metrical poetry used as a medium to teach accent, rhythm, and intonation in English, and (ii) to argue for the inclusion of training in suprasegmental features of speech in the Saudi EFL curricula, either as a separate unit or as a larger section in the current prescribed books. In a quasi-experimental study conducted at a Saudi university, a randomly selected group of 60 undergraduate EFL learners were given training in accent, rhythm, and intonation in connected speech using metrical, rhymed poetry, over a period of three weeks. A comparative analysis of the participants' pre- and post- test speech samples revealed that learners made noteworthy progress in their accent, rhythm, and intonation in connected speech.
\end{abstract}

Keywords: accent; intonation; suprasegmental features; teaching English; metrical verse 


\section{Introduction}

\subsection{The Research Background}

A living language has two prominent facets - its syntactic structure and its sound system. In the meaning-making system of the language, both the facets are complementary to each other, so much so that one has to be not only proficient in its rules of sentence formation, but also equally proficient in producing its sounds correctly. This is a common observation that native speakers of a language grasp each other's meaning just by hearing the sounds even if the words are not fully articulated. This is more so in a language like English in which sense is invariably intertwined with sound, bestowing upon it the epithet 'highly tonal language,' to a degree that the accent on a syllable and tone in the utterance change the intended meaning. Foreign language learners need to learn this aspect of the language very carefully, through specialized training in the elements of phonetics. One major factor, among several factors, such as lack of awareness of the rules of syntax, disinterest in word spellings, and lack of knowledge of word formation rules, etc. (Avery \& Ehrlich, 1992), behind the errors surfacing in the use of English by adult EFL (English as a foreign language) learners is lack of knowledge of the elements of phonetics, such as syllables, accent, and intonation in connected speech. Research in this area shows that Arabic learners of English are prone to make specific phonetic errors in English (Abdulwahab, 2015; AbiSamra, 2003; Al-Badawi, 2012; Alkhotaba \& Khan, 2017; Al-Saidat, 2010; Hago \& Khan, 2015; Shalaby, Yahya \& El-Komi, 2009). The reason for this is cited to be a mother-tongue influence, i.e., the phonological differences in the two linguistic systems (Cook, 1992; Oldin, 1989). Arabic does not follow a particular accentual pattern, so, adult Arabic speakers learning English, to their own disadvantage, transfer and impose a similar pattern upon English.

The researchers postulate that the issue of mispronunciation of English words can be tackled if adult EFL learners in Saudi Arabia are given proper training in acquiring the elements of English phonetics. Phonetics (with reference to the sound system of English) is taught in Saudi Arabia only as a specialised subject offered at English Major Course of study. Pre-university students, who are required to undergo training in English to start their university studies, but do not study English as a Major's subject have no opportunities to learn the elements of English phonetics, and are, therefore, at a loss to make up for the disadvantage and are obliged to carry forward the fossilized phonetic errors in their speech. At the most, they have to rely on the model of pronunciation, accent, rhythm and intonation on the accent of their English teachers, which may not be the standard one in many cases. At the same time, the age of the learners is also crucial since, as research has proved (Chiswick \& Miller, 2007; Lenneberg, 1967), it is easier to acquire the finer elements and nuances of pronunciation of a foreign language at a younger age, whereas, the same elements are observed to evade the grasp of an adult learner. The researchers have also postulated that since Arabic and English hardly share any linguistic features (except, perhaps, some sounds, especially some of the voiced sounds, and some similar sounding words that may be called as 'loan words' transferred culturally from one language to the other) (Al-Badawi, 2012; Alkhotaba \& Khan, 2017), an adult 
Arabic speaker learning English as a foreign language finds it inordinately difficult to acquire the English phonetic system, especially the prosodic features, with its heavy reliance on accent, rhythm and intonation. Therefore, it is essential to make things easy for such learners, and one of the ways to achieve such an objective is to take recourse to emotionally appealing learning materials, for example, poetic compositions and metrical verse lines, that may be used as examples to illustrate the finer phonetic elements of the English sound system. But, teaching of literature is not favoured in Saudi Arabia, and 'teaching language through literature' also is out of vogue. Thus, both the factors discussed above have complicated the situation for adult EFL learners, resulting in a strong emphasis on communicative competence in the syllabi at the cost of phonetic competence.

\subsection{The Problem}

The discussion above clearly indicates that teaching of English to adult EFL learners in Saudi Arabia suffers from lopsidedness. Heavy reliance on the materials intended to cater to the needs of 'functional English' syllabi, devoid of extended instructions on the prosodic features of the language, have led to the development of learners' communicative competence at the cost of their phonetic competence. Phonetic competence is one of the abilities to communicate regarding pronunciation skills (Saz, Rodríguez, Lleida, Rodríguez, \& Vaquero, 2011). There is no denying the fact that EFL learners require extensive training in accent, rhythm and intonation for mutual intelligibility in a multicultural set-up like that of Saudi Arabia. And yet, the courses and curricula are such that they have no space for phonetic competence, though not only in Saudi Arabia, this happens to be the case wherever English is taught as a foreign language as 'functional English' (Derwing \& Munro, 2005). Global research on the issue share the researchers' concern that accent training has been side-lined, or marginalised, by EFL teachers in general for various pedagogical reasons, and researchers suggest for a paradigm shift in English pedagogy (Derwing \& Munro, 2005). Although, at the same time, teachers of English worldwide have shown an increased interest in standard pronunciation, as note Derwing and Munro (2005), "as evidenced by the establishment of a TESOL interest section and a proliferation of pronunciation materials for learners" (p. 379), yet in applied linguistics research contexts "it remains a very marginalized topic" (p. 382). The researchers cite the example of The Handbook of Second Language Acquisition (Doughty \& Long, 2003), where the authors do not even bother to mention pronunciation research. Established scholars in the field, such as David Nunan (1999), Davies and Pearse (2000), Hedge (2000), Lightbown and Spada (1999), and Willis (1996), to mention only a few, show no interest either in ongoing research in pronunciation or in advocating inclusion of pronunciation training in EFL/ESL courses (Derwing \& Munro, 2005). The attitude of English educationists is reflected in EFL curricula in countries like Saudi Arabia. Grammatical and functional aspects of the English language acquire more prominence in EFL classes, while the prosodic aspects of the language, which are equally significant since they are suprasegmental features, are generally neglected. Even if the phonetic and phonological features of the target language are taught, they are taught in isolation, in a decontextualized environment, and 
are based more on drill than on cognitive or functional paradigms. The outcome, in most cases, is that a number of pre-university adult EFL learners are unable to perceive the difference between voiced and voiceless sounds and produce the kind of sentences as are reproduced below (sentences numbered a are the actual utterances of students, while sentences marked with asterisks are the probable utterances):

/p/ (bilabial, plosive, voiceless), replaced by / b/ (bilabial, plosive, voiced)

1a. *I'm go to arborat.

1b. I go to airport.

2a. *He is boles man.

$\mathbf{2 b}$. He is a police man.

3a. *I like phone ifon prad.

3b. I like iphone brand.

1a. *My father it work tetshar.

1b. My father works as a teacher.

/ $\boldsymbol{\theta} /$ (dental, fricative, voiceless), replaced by /t/ (alveolar, plosive, voiceless)

1a. *Otillo.

1b. Othello.

1a. *Meby towhours

1b. Maybe two hours.

2a. *I wiched English TW I Lat.

2b. I watched English film Twilight.

(Alkhotaba \& Khan, 2017, p. 7)

\subsection{The Research Gap}

A preliminary review of relevant literature prompted the researchers to look for any previous research studies in Saudi Arabia, or in the Arab region, discussing the issue or advocating for the inclusion of pronunciation training in adult EFL learners' course curricula. There are none. A number of studies identify mispronunciation in the oral production of learners, especially singling out some sounds (Abdulwahab, 2015; AbiSamra, 2003; Al-Badawi, 2012; Alkhotaba \& Khan, 2017; Al-Saidat, 2010; Altaha, 1995; Barros, 2003; Hago \& Khan, 2015; Shalaby et al., 2009), but no studies have highlighted the significance of accent, rhythm and intonation in connected speech. This is equally true of the research paradigms at the global level (except, of course, a few studies, such as Derwing \& Munro, 2005 and Danchenko, 2011). Second, researchers are yet unaware of the potential significance of metrical verse as examples to teach the nuances of the English sound system to adult EFL learners. First of all, research is scanty in the use of verses to encourage EFL learners' sensitivity towards elements of phonetics, without teaching them the rules of phonetics using out-of-context words and sentences. Second, there exist some ideas in the use of nonsense, rhyming words to teach phonetics since some researchers have identified a pattern in the nonsense words created by learners in their mother tongue on the patterns of English (Wong, 1991), but there are no attempts to replace nonsense words by verses (without content knowledge). Third, there are studies in the use 
of other techniques, like music beats, to teach English pronunciation, so why not use poetry?

Thus, there is a need for investigation in both the fields, especially on the expected success of verse lines to encourage EFL learners' understanding of the elements of phonetics.

\subsection{The Objectives of the Current Research}

The present research has been taken up with two objectives in mind. The first objective is to argue for a case for the inclusion of training in the basic elements of phonetics in the course curriculum of adult EFL learners in Saudi Arabia. The researchers ardently believe that teaching of the basic elements of phonetics with a view to improve foreign language learners' pronunciation should be included in the EFL curriculum for fluency building as well. The researchers suggest that this may be done either by including a separate unit in the present prescribed books or by introducing a separate booklet for the purpose. Current research studies on the issue highlight the essential need for such training. The second objective of the current research is to argue that using metrical verse lines as the literary medium to teach stress, rhythm and intonation in connected speech in English to adult EFL learners can be more productive than teaching the same using made-up sentences as examples which are commonly out of context. Metrical verse lines lend themselves to a regular rhythmic pattern, and since poetry encompasses the emotive aspects of human speech ((Beum \& Shapiro, 2006; Bloom, 2004; Brooks, 1975; Corn, 2008), a particular intonation is inscribed in its very structure, making it the fittest example of human speech to teach and learn stress, rhythm and intonation in a foreign language, which to an adult foreign language learner is otherwise the most difficult aspect of a foreign language to acquire. Since poetry is emotive, aesthetically pleasing, and lyrical so as to be easily remembered and enjoyed by learners, as well as fun to many learners, teaching accent and intonation using verse lines may be very fruitful.

The first objective of the study, that is, the argument for the inclusion of pronunciation training, draws on similar research studies that advocate for such an inclusion, while the second objective of the research is achieved through a small empirical study.

The suggested accent, rhythm, and intonation in connected speech are derived from British standard pronunciation pattern ( $\mathrm{RP}=$ Received Pronunciation). The standard pronunciation pattern followed in the study is adopted from Daniel Jones (1917/Revised edn. 2011).

\subsection{Hypotheses}

Based on the research problem and the second objective of the current research, the researchers have framed the following hypotheses:

H1: To teach the appropriate recital (in other words meter) of poetry, one has to teach - the syllable structure, stressed and unstressed syllables, primary and secondary stress, rhythm in connected speech, and finally intonation. There is a requirement to teach shift in emphasis in one's speech and accordingly shift in 
stress on structure words in place of content words (in view of their syntactic categories). This knowledge can easily be utilized to teach accent to EFL learners without putting emphasis on the poetic contents of the compositions or on the meter as such.

$H 2$ : Teaching of the basic elements of phonetics with a view to improve foreign language learners' pronunciation builds adult EFL learners' fluency in a better way.

H3: Teaching the basic elements of phonetics using metrical verse lines as examples makes the understanding of the elements easier for adult EFL learners.

\subsection{Research questions}

In order to test the hypotheses mentioned above, the following questions need to be answered through the research study:

RQ1: Does the use of metrical verse to teach elements of phonetics induce learners' sensitivity towards proper words stress, rhythm, and intonation in connected speech in English?

RQ2: Does learners' sensitivity to rime structure, pulse (beat) pattern, identification of syntactic categories of words, and shift in emphasis for meaning in verse lines help them understand the elements of phonetics better?

\section{Literature Review}

\subsection{Stress, Rhythm, Intonation}

Stress is generally defined from the points of view of production and perception. For instance, Peter Roach (2009) explains that in production, the speaker uses more muscular force for a stressed syllable compared to the unstressed one. From the point of view of perception, the stressed syllable stands out to be prominent owing to four factors - (i) loudness, (ii) length, (iii) pitch, and (iv) quality. The same applies to primary and secondary stress in polysyllabic words - primary stress is comparatively more prominent than secondary stress.

Rhythm in speech is a matter of timing. As regards rhythm in English speech, Peter Roach (2009) notes that "It has been often claimed that English speech is rhythmical, and that the rhythm is detectable in the regular occurrence of stressed syllables" (p. 107). The theory commonly accepted on the nature of rhythm in English is that English has stress-timed rhythm, which "implies that stressed syllables will tend to occur at relatively regular intervals whether they are separated by unstressed syllables or not" (p. 107), though Roach observes that stress-timed rhythm is "perhaps characteristic of one style of speaking, not of English speech as a whole" (p. 109) since he notices that English people may speak very rhythmically at times, while at other times they may speak arhythmically. As regards defining intonation, Roach's (2009) observation is that "No definition is completely satisfactory, but any attempt at definition must recognise that the pitch of the voice plays the most important part" (p. 119). Pitch in speech is described as 'high' and 'low' though these are arbitrary terms since, as observes Roach (2009), "It would be perfectly reasonable to think of pitch as ranging instead from "light" to "heavy," for example, or from "left" to "right" (p. 119). What we study in 'intonation' is the change in the pitch of the speaker's voice that carries some linguistic information, especially when the speaker has 
full control over the pitch in his/her voice (Balasubramanian, 1981; Collins \& Mees, 2013; Knowles, 2014; Ogden, 2009; Wong, 1987). So, following Peter Roach (2009) and other linguists, in looking for linguistically significant aspects of speech (for instance, pitch) we must always be looking for contrasts. To determine that a change in pitch has brought about a change in the speaker's meaning, we must be able to establish a perceptible contrast in the beginning and the changed pitch, as well as a unit to measure it. To achieve this, linguists set something called "level pitch," against which are perceived the changes: the pitch either moving up or down the 'level' scale. 'Tone' is the word used for the overall behaviour of the pitch. Thus, a speaker may use 'level,' 'rising' or 'falling' tone, or a mix of the two in his/her speech. Accordingly, meanings and intentions of the speaker are derived.

All this can be taught to adult EFL learners in an interesting manner using metrical poetry as example speech (Lengeris, 2012; Ti, 2017). The rhyme, rhythm, and tone create the appropriate metrical lines. The prosodic features of English can be taught in a better, contextualised manner to adult EFL or ESL learners without extensive focus on the poetic content, and with an emphasis only on the formal aspects of a poem. The learners are not supposed to scan a poem; they will be given poems marked with stressed and unstressed syllables, feet divisions and beat timing. Moreover, the learners will be learning more about contraction, elision and hiatus. For instance, syllables in poetic lines are often mashed together and, and accordingly, words like "over" can be monosyllabic (example of elision) or disyllabic (example of hiatus). Affixes (prefixes and suffixes) may or may not count as full syllables, and so on.

\subsection{Beat vs. stress}

Stress and beat are two different notions, though most often stress is the beat in poetry since beat is created by stress. And yet, to maintain the beat, quite often structure words that are not generally stressed are also stressed in verse lines. For example, look at the following verse lines in which structure words, such as 'are,' 'up' and 'in' are stressed (the stressed syllables are in bold font):

\section{Twinkle twinkle little star}

How I wonder what you are

Up above the world so high

Like a diamond in the sky.

This brings us to the significance of what the speaker wishes to highlight, a very significant point in pronunciation training. Most often secondary stress (which is commonly ignored) is also made use of in creating beats in poetry (Commercial Poetry, 2013).

\subsection{Previous Studies}

As has been pointed out, there is a complete lack of research studies on the issue of non-inclusion of pronunciation training in the EFL curricula, either in Saudi Arabia or in the Arab region. Of course, the major reason for that is the emphasis in their education system on developing "communicative competence," as regards foreign language teaching. The focus on 'language teaching,' on the 
other hand, leads to a complete neglect of teaching of literature at universities in the Arab region, which is linked to our second research objective. Since the EFL learners are hardly acquainted with English poetry and poetic meter, they cannot be blamed for not being aware of stress, intonation, rhyme, and stresstimed rhythm in English language in general. There are a number of studies on the pronunciation problems of Arab speaking students learning English, and there are ample studies on teaching the elements of phonetics, but there are no studies focused on using metrical verse as examples to make that learning easier.

Poetry has been put to various uses, apart from its primary use as an object of aesthetic enjoyment (Cahnmann-Taylor, Zhang, Bleyle \& Hwang, 2015; d'Abdon, 2016; Harfitt \& Chu, 2011; Khatib, 2011; Pushpa \& Savaedi, 2014; Wiseman, 2010). Take, for example, the research study by Harfitt and Chu (2011) that used poetry to engage adult EFL teacher-trainees towards language and meaning facilitating free expression of opinions and feelings. The researchers repost satisfactory success with their experiment. Wiseman (2010) made use of poetry to facilitate learning among adult EFL learners by attending to students' emotions and background knowledge and "encouraging social collaboration, and providing an authentic purpose for students to communicate through their writing" (p. 22) and found that poetry works well with learners. d'Abdon (2016) also claims that poetry is not a dead word on a page; it can perform various socio-political acts, like the researcher used spoken word poetry as a tool for decolonizing and Africanizing the South African curricula. Poetry has been reported to be a successful tool in creating an East-West contact zone for scholars in TESOL teacher education (Cahnmann-Taylor et al., 2015). The researchers emphasize the arts-based learning opportunities work to expand all students' potential for double vision, creating vibrant Eastern-Western exchanges of intellectual thought and intercultural understanding. Poetry, as observe Collie and Slater (1990), has also been used for four different purposes in language classes: as valuable authentic material, for cultural enrichment, language enrichment, and personal involvement (pp. 5-7). Khatib (2011) realizes that teaching of literature, and particularly of poetry, has been sidelined in language classrooms, but of late, there has been a renewed interest in teaching of literature in language classrooms. Çetinavc1 and Tütüniş (2012) also lay stress upon the renewed interest of learners in learning English awakened through the use of poetry. But, none of the studies reviewed above have exploited poetry to teach the finer elements of phonetics in prosaic speech, justifying the need for the present study.

Similarly, studies abound on teaching phonetics and the finer aspects of pronunciation to EFL students using several methods and techniques, but none of the researchers have experimented with poetry. For example, Mitrofanova (2012) investigated the importance of EFL students' awareness of English extended pitch sequences realised within complex utterances and text subtopics, especially its influence on reading intelligibility, and found it does affect text information of students. Saz et al. (2011) have experimented with multimodal tools for pronunciation training in second language for preadolescent learners and reported satisfactory results. Hahn (2004), in an 
interesting study, examined native English speakers' reactions to non-native primary stress in English discourse. The researcher hypothesised that if nonnative speakers place primary stress correctly, they are mostly intelligible to native speakers, otherwise not. These results are encouraging for the current study as well, emphasizing the significance of learning correct stress. The research conducted by Wong (1991) is also interesting as it attempted to find a pattern in English word stress through creating a list of nonsense words in learners' mother-tongue.

But, as the researchers have mentioned time and again, none of the studies reviewed so far have investigated the potentials of English metrical verse to teach the nuances of stress, rhythm, and intonation in English to adult EFL learners. It is only Reppert's (2004) study (for Master's degree) which is somewhat similar to the present study as the researcher used children's verse literature, along with adult literature, once again in verse form, to measure the effect of poetry and children's literature in verse on fluency development of adult ESL learners (Chinese-speaking graduate students at Iowa State University), and found "a very slight, though statistically significant, increase in fluency for some participants when responding to a reading prompt" (p. v). The success story reported by Reppert has encouraged the present researchers to experiment with metrical poetry to teach the nuances of pronunciation to adult EFL learners.

\section{Research Design}

The present study has been designed as a quasi-experimental, confirmatory research, working on a stated problem. The researcher started with a set of preconceived hypotheses the empirical truths of which were to be confirmed through analysis of data collected in an experiment on the effects of teaching metrical poetry on the phonetic competence of undergraduate EFL learners.

\subsection{Research Methodology and Procedure}

The mixed-research method has been employed in the study. Quantitative approach has been used to collect numerical data, while qualitative methodology has been adopted to interpret the obtained numerical results on the hypotheses regarding the second research objective. The experimental program involved teaching of metrical, rhymed verse to participants, and preand post- test sampling of their speech in English. The test variables were stress, rhythm, and intonation in connected speech.

The experimental program was conducted at King Abdulaziz University in Saudi Arabia to test whether poetic intervention helps enhance the phonetic competence of adult EFL learners. The data, i.e., speech samples taken from participants before and after the experimental program, were tested and judged by native-speaker university teachers as well as through the software Rosetta Stone. Initially, the learners were given to memorize a few limericks nursery rhymes with proper accentual patterns, without teaching them the elements of phonetics, such as the syllable, rhythm, and intonation. It was followed by teaching them five limericks (There was once a man from Nantucket; An 
infatuated man from Dover; A Texas Tech grad who's a Saudi; A baker who traded in Duns; We're hearing that Eleanor White) and finally the participants were given to recite five metrical verses (The Tyger; An Essay on Man; Lucy Gray; Hope is the Thing with Feathers; La Belle Dame sans Merci) with proper rhyme, rhythm and intonation, without teaching them either the elements of phonetics or the meter in English poetry. Experimental classes were conducted after the usual teaching hours, for 30 minutes every day for three weeks.

\subsection{Research Setting, Sample Size and the Participants}

A total of 60 students (out of the total population of roughly 600 students) were selected to participate in the present study, through random selection technique. The reasons for random selection were (i) better generalizability of results and (ii) avoidance of possible bias in selection. The participants were Preparatory Year students learning English as a Foreign Language, at the Rabigh campus of King Abdulaziz University, Jeddah in Saudi Arabia, who are taught English for one year prior to be enrolled for their selected major courses, with a clear emphasis on the functional aspects of the target language; they are not given any training in phonetics, except that at the end of some units in the prescribed books (called 'authentic materials') is provided some information on word stress and stressed/unstressed syllables/words. Their English teachers are not provided with any instructional materials to teach the elements of phonetics and standard pronunciation, such as stress, rhythm and intonation in connected speech.

\subsection{Measurement Technique}

As mentioned above, speech samples from participants were taken before and after the experimental program that lasted for three weeks. The participants were taught to recite metrical, rhymed poetry in proper accent and rhythm. Since the larger number of EFL teachers on Rabigh campus are non-native speakers, evaluation of participants' progress was carried out with the help of native-speaker teachers at the varsity. In addition, the software Rosetta Stone proved to be very helpful in evaluating the accent. The software provides reading prompts that present the next item in the list to the user only if the item at hand is pronounced correctly.

\section{Discussion and Analysis}

\subsection{Discussion}

In a simple experiment, 60 pre-university participants were given indirect training in English pronunciation by providing them with a few nursery rhymes, a selection of limericks, and a few metrical verses. Samples of the participants' speech were recorded before the experiment, which were marked for correctness of stress, rhythm, and intonation by native-speaker teachers at the selected university. The researchers recited the verse lines to the class before distributing the materials to participants. In addition, audio files of the selected verses were played on the laptop for an authentic recital. Along with the hard copy of the verses, participants were also given the audio version of the same to listen and practice at home. In the classes the next day, the participants were asked to recite the poems before fresh poems were handed out to them. At the end of the experiment, samples of participants' speech reading out prose sentences were 
recorded. Participants read out twenty test sentences of varying length and varying kinds (assertive, interrogative, imperative and exclamatory). Excerpts of approximately 45 seconds from each participant were selected for evaluation and rating by native speaker teachers. The judging teachers were unaware whether or not a sampled student had participated in the experimental teaching. Similar previous studies are found to have selected shorter or longer duration excerpts (Derwing \& Munro (1997) - 4.5 to 10.5 seconds; Derwing \& Rossiter (2003) - 45 seconds; Reppert (2004) - 30 seconds. At the same time, participants were asked to complete the higher level speaking tests at Rosetta Stone.

\subsection{Analysis and Interpretation of Results}

The rating of the judges showed that compared to pre-experiment pronunciation and fluency (with rhythm and intonation) of the participants, post-experiment pronunciation and fluency displayed marked improvement. The pre-experiment speech samples of only 6 participants $(10 \%)$ cleared the test for primary stress, secondary stress, fluency, and intonation with 34\% accuracy. The same participants could reach Level 2 at Rosetta Stone. The post-experiment speech samples of $45(75 \%)$ participants were found to clear the test with $80 \%$ accuracy for primary stress, secondary stress, fluency and correct falling, rising or risingfalling tone. Almost a similar number of participants cleared Level 4 at Rosetta Stone. The summarised results are presented in Table 1 below:

Table 1: Results Obtained from Evaluation of Participants' Speech Samples

\begin{tabular}{|c|c|c|c|c|c|c|c|}
\hline Stage & No. of & $\%$ & \multicolumn{5}{|c|}{ Features of Pronunciation } \\
\hline \multirow{2}{*}{$\begin{array}{c}\text { Pre- } \\
\text { Experiment }\end{array}$} & \multirow{2}{*}{6} & \multirow{2}{*}{10} & \multirow{2}{*}{ Accuracy (\%) } & $\begin{array}{c}\text { Primary } \\
\text { Stress }\end{array}$ & \begin{tabular}{|c|} 
Secondary \\
Stress
\end{tabular} & $\begin{array}{l}\text { Fluency } \\
\text { (Rhythm) }\end{array}$ & Tone \\
\hline & & & & 34 & 30 & 22 & 20 \\
\hline $\begin{array}{c}\text { Post- } \\
\text { Experiment }\end{array}$ & 45 & 75 & Accuracy (\%) & 75 & 75 & 80 & 80 \\
\hline
\end{tabular}

\section{Conclusion}

The current study was taken up with two objectives in view. The first objective was to argue for the inclusion of pronunciation training in adult EFL learners' curriculum of study in Saudi Arabia. This objective was not to be achieved through any empirical research as it was only an argument making a case. The argument was based on research in the area advocating for a strong need for such training for EFL learners, not only in Saudi Arabia but in all EFL teaching/learning contexts (Derwing \& Munro, 2005; Jenkins, 2004). The current research was inspired by Derwing and Munro (2005) who vehemently advocate for the teaching of pronunciation as well as research in this area highlighting its potential benefits: "Research of this type has much to offer to teachers and students in terms of helping them to set learning goals, identifying appropriate pedagogical priorities for the classroom, and determining the most effective approaches to teaching" (p. 379). The findings of the present study show that adult EFL learners in Saudi Arabia have no training in pronunciation in English, while they essentially need it. 
The second objective of the study was to find out if metrical English verse lines can be used as example speech to teach the finer aspects of English pronunciation to adult EFL learners in Saudi Arabia for better results. This objective was to be achieved through an empirical study answering a set of research questions. The findings of the study support the three hypotheses that (i) to teach the recital of poetry, one has to teach - the syllable structure, stressed and unstressed syllables, primary and secondary stress, rhythm in connected speech, intonation, and stress shift. This knowledge can be utilized to teach accent to EFL learners, (ii) teaching of the basic elements of phonetics with a view to improve foreign language learners' pronunciation builds adult EFL learners' fluency in a better way, and (iii) teaching the basic elements of phonetics using metrical verse lines as examples makes the understanding of the elements easier for adult EFL learners. All the three hypotheses are supported by research. There were no previous studies in this research area to compare the present findings with, but the findings of the study answer the research questions satisfactorily.

\section{Limitations of the Present Study}

It was hard to anticipate the possible limitations of the study at the outset, however, as the research progressed, a few hindrances, given below, were observed, that might have affected the results:

(a) The area of study investigated in the current research is hitherto largely unexplored, so, there are no previous studies to compare the research findings with, to visualize the findings in a perspective;

(b) For the lack of enough time and resources, the study was limited to a small number of participants. The similar experiments conducted with a larger population of EFL learners might provide us with better generalizable results.

\section{Strengths and Weaknesses of the Present Study}

The primary strength of the study lies, first, in the fact that it raises a dormant issue concerning teaching of English to adult EFL learners in Saudi Arabia. All university English teachers feel the need for pronunciation training for their students but advocacy for the case is missing for lack of research in the area. The second strength of the study is its being a pioneering research in arguing for the use of metrical poetry to teach pronunciation highlighting its potential benefits.

However, the study is based on a quasi-experimental design, and for lack of resources the researchers could not make use of extensive statistical analysis of the obtained results to argue for the case even more strongly. This might be considered as a weakness of the study.

\section{Further Recommendations}

The present study has been a small-scale experiment. The favourable results obtained from the experiment are indicative of the fact that further experiments may repeat the success in a different setting, at a larger scale. More experiments with higher success rate, especially in Saudi Arabia, will make the case stronger 
for the recommendation of the inclusion of pronunciation training in adult EFL learners' curriculum of study in Saudi Arabia.

\section{References}

Abdulwahab, H. A. (2015). Difficulties of English Pronunciation Encountered by Saudi Learners (Unpublished M.A. Thesis). Open University of Sudan, Khartoum, Sudan.

AbiSamra, N. (2003). An Analysis of Errors in Arabic Speakers' English Writings. Retrieved from http://abisamra03.tripod.com/nada/languageacq-erroranalysis.html

Al-Badawi, K. (2012). An Analysis of Phonological, Morphological and Syntactic Errors in English: A Case Study of Saudi BA Students at King Khalid University. International Journal of Social Science and Humanity, 2(6), 536-38. doi:10.7763/ijssh.2012.v2.165

Alkhotaba, H., \& Khan, A. A. (2017). Linguistic Analysis of Patterned Sentence Errors in English: A Case Study of Preparatory Year Saudi University Students. International Journal of Language Learning \& Applied Linguistics Word, 16(4), 1-21. Retrieved from https://f8570e61-768a4fd98a33a2e351ee8e07.filesusr.com/ugd/6bee84_077fcbf788f64f73a450ce0451e17 $1 \mathrm{cf.pdf}$

Al-Saidat, E. M. (2010). Phonological Analysis of English phonotactics: A Case Study of Arab Learners of English. The Buckingham Journal of Language and Linguistics, 3, 121-134. doi:10.5750/bjll.v3i0.26

Altaha, F. M. (1995). Pronunciation Errors made by Saudi university students learning English: analysis and remedy. International Review of Applied Linguistics, 109(1), 110-123. doi: 10.1075/itl.109-110.05alt

Avery, P., \& Ehrlich S. (1992). Teaching American English Pronunciation. Oxford: Oxford University Press.

Balasubramanian, T. (1981). A Textbook of English Phonetics for Indian Students (2nd edn.). Madras: Macmillan India Ltd.

Barros, A. M. (2003). Pronunciation difficulties in the consonant system experienced by Arabic speakers when learning English after the age of puberty (Master's Dissertation). West Virginia University, Morgantown, USA. Retrieved from https:// researchrepository.wvu.edu/cgi/viewcontent.cgi?article=1769\&context $=$ etd

Beum, R., \& Shapiro, K. (2006 [1965]). The Prosody Handbook: A Guide to Poetic form. New York: Dover.

Bloom, H. (2004). The Art of Reading Poetry. New York: HarperCollins.

Brooks, C. (1975 [1942]). The Well Wrought Urn: Studies in the Structure of Poetry. New York: Houghton Mifflin Harcourt.

Cahnmann-Taylor, M., Zhang, K., Bleyle, S. J., \& Hwang, Y. (2015). "Searching for an entrance" and finding a two-way door: Using poetry to create East-West contact zones in TESOL teacher education. International Journal of Education $\mathcal{E}$ the Arts, 16(21), 1-29. Retrieved from http://www.ijea.org/v16n21/

Çetinavcı, U. R., \& Tütüniş, B. (2012). Making Use of Poems to Teach English. The Journal of Language Teaching and Learning, 2(2), 75-88. Retrieved from http://jltl.com.tr/index.php/jltl/article/view/97/15

Chiswick, B. R., \& Miller, P. W. (2007). The Critical Period Hypothesis for Language Learning: What the 2000 US Census Says. IZA Discussion Paper No. 2575. Retrieved from https://ssrn.com/abstract $=961386$ 
Collie, J., \& Slater, S. (1990). Literature in the Language Classroom: A Resource Book of Ideas and Activities. Cambridge: Cambridge University Press.

Collins, B., \& Mees, I. M. (2013). Practical Phonetics and Phonology (3rd edn.). New York: Routledge.

Commercial Poetry. (2013). Scansion for Beginners [Blog post]. Retrieved from http://commercialpoetry.blogspot.com/2013/07/scansion-forbeginners_31.html

Cook, V. J. (1992). Evidence for Multicompetence. Language Learning, 42(4), 557-591. doi:10.1111/j.1467-1770.1992.tb01044.x

Corn, A. (2008). The Poem's Heartbeat: A Manual of Prosody. Port Townsend, WA: Copper Canyon Press.

d'Abdon, R. (2016). Teaching spoken word poetry as a tool for decolonizing and Africanizing the South African curricula and implementing "literocracy." Scrutiny2, 21(2), 44-62. doi:10.1080/18125441.2016.1192676

Danchenko, N. (2011). Pronunciation and Independent Work: Embedding Pronunciation into Academic English Skill Classes. Advances in Language and Literary Studies, 2(2), 171-184. doi:10.7575/aiac.alls.v.2n.2p.171

Davies, P., \& Pearse, E. (2000). Success in English Teaching. Oxford: Oxford University Press.

Derwing, T. M., \& Munro, M. J. (1997). Accent, Intelligibility, and Comprehensibility: Evidence from Four L1s. Studies in Second Language Acquisition, 19(1), 1-16. doi:10.1017/S0272263197001010

Derwing, T. M., \& Munro, M. J. (2005). Second Language Accent and Pronunciation Teaching: A Research-Based Approach. TESOL Quarterly, 39(3), 379-397. doi: $10.2307 / 3588486$

Derwing, T. M., \& Rossiter, M. J. (2003). The Effects of Pronunciation Instruction on the Accuracy, Fluency, and Complexity of L2 Accented Speech. Applied Language Learning, 13(1), 1-17.

Doughty, C. J., \& Long, M. H. (Eds.). (2003). The handbook of second language acquisition. Blackwell. doi:10.1002/9780470756492

Hago, O. E., \& Khan, W. A. (2015). The Pronunciation Problems Faced by Saudi EFL Learners at Secondary Schools. Education and Linguistics Research, 1(2), 85-89. doi:10.5296/elr.v1i2.7783

Hahn, L. D. (2004). Primary Stress and Intelligibility: Research to Motivate the Teaching of Suprasegmentals. TESOL Quarterly, 38(2), 201-223. doi:10.2307/3588378

Harfitt, G., \& Chu, B. (2011). Actualizing Reader-Response Theory on L2 Teacher Training Programs. TESL Canada Journal, 29(1), 93-103. doi:10.18806/tesl.v29i1.1091

Hedge, T. (2000). Teaching and Learning in the Language Classroom. Oxford: Oxford University Press.

Jenkins, J. (2004). Research in Teaching Pronunciation and Intonation. Annual Review of Applied Linguistics, 24, 109-125. doi:10.1017/S0267190504000054

Jones, D. (2011). Cambridge English Pronouncing Dictionary (18 ${ }^{\text {th }}$ edn.), edited by Peter Roach, Jane Setter and John Esling. Cambridge: Cambridge University Press.

Khatib, M. (2011). A New Approach to Teaching English Poetry to EFL Students. Journal of Language Teaching and Research, 2(1), 164-169. doi:10.4304/jltr.2.1.164-169

Knowles, G. (2014). Patterns of Spoken English: An Introduction to English Phonetics. New York: Routledge. 
Lengeris, A. (2012). Teaching and learning English prosody: Lessons from L2 speech perception and production research. In J. Romero-Trillo (ed.), Pragmatics and Prosody in English Language Teaching (25-40). Netherlands: Springer.

Lenneberg, E. H. (1967). Biological Foundations of Language. John Wiley \& Sons.

Lightbown, P. M., \& Spada, N. (1999). How Languages are Learned. Oxford: Oxford University Press.

Mitrofanova, Y. (2012). Raising EFL students' awareness of English intonation functioning. Language Awareness, 21(3), 279-291. doi:10.1080/09658416.2011.609621

Nunan, D. (1999). Second Language Teaching and Learning. Boston: Heinle \& Heinle.

Ogden, R. (2009). An Introduction to English Phonetics. Edinburgh: Edinburgh University Press.

Oldin, T. (1989). Language Transfer: Cross-linguistic influence in language learning. Cambridge: Cambridge University Press.

Pushpa, V. K., \& Savaedi, S. Y. (2014). Teaching Poetry in Autonomous ELT Classes. Procedia - Social and Behavioral Sciences, 98, 1919-1925. doi:10.1016/j.sbspro.2014.03.623

Reppert, K. R. (2004). Literature and the development of oral fluency: A study using poetry and children's literature in adult ESL instruction (Master's Dissertation). Iowa State University, Ames, USA. Retrieved from https:/ /lib.dr.iastate.edu/cgi/viewcontent.cgi?article $=17215 \&$ context $=$ rtd

Roach, P. (2009). English Phonetics and Phonology: A Practical Course ( $4^{\text {th }}$ edn.). Cambridge: Cambridge University Press.

Saz, O., Rodríguez, V., Lleida, E., Rodríguez, W. R., \& Vaquero, C. (2011). The Use of Multimodal Tools for Pronunciation Training in Second Language Learning for Preadolescents. Journal of Communications Research, 3(1), 1-19. Retrieved from http:/ / web.b.ebscohost.com/ehost/pdfviewer/pdfviewer?vid=1\&sid=7e5f021fece2-4de2-924d-682109f2a0b5\%40pdc-v-sessmgr04

Shalaby, N. A., Yahya, N., \& El-Komi, M. M. (2009). Analysis of Lexical Errors in Saudi College Students' Compositions. 'Ayn, Journal of the Saudi Association of Languages and Translation, 2(3), 65-93. Retrieved from https://fac.ksu.edu.sa/sites/default/files/Analysis_of_Lexical_Errors.pdf

Ti, Calvin. (2017). Perfect Your English Pronunciation With This Poem - Part 1. Blogpost, Retrieved from https://www.verbling.com/articles/post/perfect-your-englishpronunciation-with-

Willis, J. (1996). A Framework for Task-Based Learning. Essex, England: Longman.

Wiseman, A. M. (2010). "Now I believe if I write I can do anything": Using poetry to create opportunities for engagement and learning in the language arts classroom. Journal of Language and Literacy Education, 6(2), 22-33. Retrieved from https:// files.eric.ed.gov/fulltext/EJ1068168.pdf

Wong, C. S. P. (1991). The Stress Patterns of Nonsense English Words of CantoneseSpeaking ESL Learners. CUHK Papers in Linguistics, 3, 83-111. Retrieved from https:/ / files.eric.ed.gov/fulltext/ED363102.pdf

Wong, R. (1987). Teaching Pronunciation: Focus on English Rhythm and Intonation. Washington, DC: Prentice-Hall Regents. 